\title{
MICROPROPAGAÇÃO DE ERVA-MATE A PARTIR DE SEGMENTOS NODAIS ${ }^{1}$
}

\author{
MICROPROPAGATION OF THE ERVA-MATE \\ THROUGH CULTURE OF NODAL SEGMENTS
}

\author{
Solange Ribas ZANIOLO ${ }^{2}$ \\ Flávio ZANETTE ${ }^{3}$
}

\begin{abstract}
RESUMO
Considerando a dificuldade de obtenção de mudas de erva-mate por sementes, a micropropagação apresenta-se como uma alternativa para a produção de plantas selecionadas. $\mathrm{O}$ presente trabalho foi conduzido no Laboratório de Micropropagação Vegetal da Universidade Federal do Paraná, durante os anos de 1991 e 1992, com o objetivo de se estabelecer um protocolo de micropropagação para a erva-mate. Segmentos nodais foram desinfestados em solução de 0,50 ou $0,75 \%$ de $\mathrm{NaOCl}$ durante 5,10 ou $15 \mathrm{~min}$. A desinfestação das brotações foi eficiente com $0,75 \%$ de $\mathrm{NaOCl}$ por 10 min, onde se obteve $20,1 \%$ de contaminação, $5,7 \%$ de oxidação e $72,9 \%$ de sobrevivência dos explantes. Na obtenção de brotações múltiplas testou-se a adição de auxina (AIB) combinada com citocinina (BAP) nos meios MS e WPM durante três subcultivos. A permanência de brotações durante três subcultivos no mesmo meio de cultura (WPM + 8.87 $\mu \mathrm{M}$ BAP) proporcionou a maior taxa de multiplicação (3,75 brotações/explante). O enraizamento foi avaliado em duas fases (indução e alongamento das raízes) durante $12+18$ dias e em fase única durante 30 dias, empregou-se diferentes concentrações de AIB no meio WPM/2 e meio WPM $/ 2+1 \mathrm{~g} \cdot \mathrm{L}^{-1}$ de carvão ativado. O enraizamento em duas fases proporcionou melhor enraizamento $(86,2 \%)$ com um número médio de 8,2 raízes/explante. As mudas enraizadas tiveram bom desenvolvimento após o transplante para a terra.
\end{abstract}

Palavras-chave: Ilex paraguariensis, propagação in vitro, enraizamento in vitro.

\begin{abstract}
Considering the fact that is difficult to obtain stocks from erva-mate (Ilex paraguariensis St. Hil.) by seeds, microprogation is recommended as an alternative for selected plant production. This work was carried out in the Plant Micropropagation Laboratory at the Universidade Federal do Paraná in 1991 and 1992 to establish a micropropagation protocol for erva-mate. Nodal segments were desinfested in a 0.50 or $0.75 \% \mathrm{NaOCl}$ solution during 5,10 or $15 \mathrm{~min}$. Efficient shoot desinfestation was achieved with $0.75 \% \mathrm{NaOCl}$ solution for $10 \mathrm{~min}$, showed $20.1 \%$ contamination, $5.7 \%$ oxidation and $72.9 \%$ of the nodal segments survival. In the multiplication phase IBA and BAP combinations were tested in WPM and MS media in three subcultures. Maximum shoot regeneration was achieved when nodal segments were maintained in the three subcultures. The greatest proliferation rate (3.75 shoots/explant) was in WPM $+8.87 \mu \mathrm{M}$ BAP. Rooting was evaluated in two steps (induction and elongation of roots) during $12+18$ days and in one step during 30 days, with different concentrations of IBA in WPM/2 and WPM/2 + 1 g. $L^{-1}$ of actived charcoal. The two steps root formation provided the greatest rooting $(86.2 \%)$ and number of 8.2 roots/shoot. Development was good in plantlets rooted.
\end{abstract}

Key words: llex paraguariensis, in vitro propagation, in vitro rooting.

${ }^{1}$ Parte da Dissertação de Mestrado apresentada pela primeira autora à UFPR.

2 Bióloga, CRB 25.443-03, Mestre, Doutoranda no Programa de Pós-Graduação da Universidade Federal do Paraná, Departamento de Fitotecnia e Fitossanitarismo, Rua Professor Dario Vellozo, 650, Apartamento 3, CEP 80320-050, Curitiba, PR, Bolsista da CAPES. - Autor para correspondência.

3 Engenheiro Agrônomo, CREA 4064, Doutor, Universidade Federal do Paraná, Departamento de Fitotecnia e Fitossanitarismo, Professor Titular, Curitiba, PR. 


\section{INTRODUÇÃO}

A erva-mate (Ilex paraguariensis St. Hil.) é uma espécie nativa de Brasil, Bolívia, Paraguai, Uruguai e Argentina. Sua área de ocorrência no Brasil corresponde aos estados de Mato Grosso, São Paulo, Paraná, Santa Catarina e Rio Grande do Sul [5]. Apesar de ser utilizada há muito tempo na forma de chá-mate e chimarrão, o conhecimento da biologia desta espécie é ainda insuficiente. Essa espécie, como todas as outras componentes da floresta nativa paranaense, teve seu número reduzido em grandes proporções devido à devastação. A exploração madeireira e principalmente o desmatamento para a expansão da agricultura diminuíram sensivelmente a cobertura vegetal [14].

Os problemas com os quais se depara o cultivo mediante sementes são a produção de plantas muito heterogêneas, o baixo poder germinativo das sementes e o tempo excessivamente longo de sua germinação. O gênero llex tem sementes dormentes por imaturidade embrionária [12]. Sendo assim, o emprego de técnicas de multiplicação vegetativa apresenta-se como alternativa para a propagação de plantas selecionadas.

$\mathrm{Na}$ última década tem havido avanços significativos no desenvolvimento da cultura de tecidos, especialmente de espécies lenhosas [2]. Rey e Mroginski [21] obtiveram a regeneração de erva-mate pelo cultivo in vitro a partir de segmentos nodais, com enraizamento de $50 \%$ das brotações. Cunha [3] e Ferreira et al [6] testaram a germinação de embriões de erva-mate cultivados in vitro. Rey et al [22] também testaram meios de cultura para o estabelecimento, in vitro, de explantes de erva-mate a partir de segmentos nodais, explantes foliares e cultura de células. Mais recentemente, Sansberro et al [26] obtiveram a regeneração de erva-mate in vitro a partir de segmentos nodais e meristema apical e verificaram uma taxa de enraizamento de $60 \%$. Entretanto, ainda existem aspectos que devem ser investigados com o objetivo de melhorar a eficiência dessa técnica por meio do estudo de alguns fatores envolvidos nas etapas de desinfestação, obtenção de brotações múltiplas e enraizamento dessa espécie.

\section{METODOLOGIA}

\section{Obtenção dos explantes}

Como fonte de explantes utilizaram-se 350 mudas de erva-mate com dois anos de idade. As mudas matrizes foram mantidas em casa de vegetação climatizada, instalada no Setor de Ciências Agrárias da Universidade Federal do Paraná. As mudas receberam pulverizações semanais com o fungicida benomyl na concentração de $2 \mathrm{~g} . \mathrm{L}^{-1}$ por aplicação durante todo o período de coleta de explantes (1991 e 1992).

\section{Desinfestação e isolamento do material vegetal}

As brotações coletadas em casa de vegetação foram cortadas e as folhas retiradas, lavadas em água com detergente e enxaguadas. Em seguida foram transferidas para uma solução de $\mathrm{NaOCl}$ ( $5 \%$ de $\mathrm{Cl}$ livre) nas concentrações de 0,50 e $0,75 \%$ com $0,01 \%$ de tween 20 . Posteriormente, procedeu-se a lavagem dos explantes em água deionizada e esterilizada por quatro vezes, permanecendo os explantes imersos até 0 isolamento. As brotações foram cortadas em segmentos com aproximadamente $3 \mathrm{~cm}$ e inoculadas em tubo de ensaio contendo o meio básico MS [19] e transferidas para sala de incubação. Esse experimento foi realizado no mês de setembro, utilizando-se 70 explantes/tratamento. Após um mês foram avaliadas as percentagens de sobrevivência, oxidação e contaminação por fungos e bactérias.

\section{Condições ambientais das culturas}

Nas fases de isolamento, obtenção de brotações múltiplas e enraizamento, as culturas foram mantidas em sala de incubação, com controle de temperatura $\left(25 \pm 2^{\circ} \mathrm{C}\right)$, fotoperíodo $(16 \mathrm{~h})$ e intensidade luminosa $\left(25 \mu \mathrm{E} \mathrm{s}^{-1} \mathrm{~m}^{-2}\right)$.

\section{Obtenção de brotações múltiplas}

Os explantes utilizados foram brotações subapicais oriundas da fase de isolamento e que apresentavam 2 a $3 \mathrm{~cm}$ de comprimento. O número de amostras variou entre 15 e 40 explantes/tratamento. Os tratamentos consistiram de combinações de BAP $(8,87 \mu \mathrm{M})$ e AIB $(0 ; 0,24 ; 0,98$ e $1,48 \mu \mathrm{M})$ nos meios MS e WPM (17) durante três subcultivos. As culturas foram avaliadas após 30,60 e 90 dias com relação ao número de brotações múltiplas e aproveitáveis $(>0,5 \mathrm{~cm})$ por explante. As taxas de multiplicação foram avaliadas pelo teste de KruskalWallis (Kw) e análise de regressão.

\section{Enraizamento e transplante das mudas}

Foram utilizadas brotações de 2 a $3 \mathrm{~cm}$ de comprimento com a extremidade basal cortada em forma de cunha. O meio de cultura escolhido foi WPM/2, variando-se as concentrações de AIB (0; 14,$7 ; 19,6$ e $24,6 \mu \mathrm{M}$ ) e ao final de 30 dias avaliouse 0 enraizamento. Também se testou o enraizamento em duas fases no meio WPM/2. Na $1^{\text {a }}$ fase (indução) foi adicionado 0;14,7; 19,6 e $24,6 \mu \mathrm{M}$ de AIB e na $2^{\mathrm{a}}$ fase (desenvolvimento) foi acrescentado ao meio básico $1 \mathrm{~g} \cdot \mathrm{L}^{-1}$ de carvão ativado. As brotações foram mantidas em meio de indução durante 12 dias e transferidas para meio de desenvolvimento por 18 dias. $\mathrm{O}$ número de amostras foi de 30 explantes/tratamento e os dados resultantes foram avaliados pelo teste de KruskallWallis e análise de regressão por meio de 
polinômios ortogonais. Avaliou-se também o número médio de raízes/explante.

Após 30 dias as raízes foram lavadas em água e cortadas. O transplantio foi feito em bandeja de semeadura com terra e as mudas irrigadas diariamente até quatro vezes durante os sete primeiros dias. Esse procedimento foi realizado em casa de vegetação climatizada.

\section{RESULTADOS E DISCUSSÃO}

\section{Desinfestação e isolamento}

a) Contaminação

A imersão dos explantes durante $15 \mathrm{~min}$ em solução de $\mathrm{NaOCl}$ a $0,75 \%$, foi o tratamento mais efetivo para a desinfestação, resultando em taxas médias de contaminação de $14,2 \%$ para bactérias e $5,7 \%$ para fungos. Esse resultado é similar ao verificado para $10 \mathrm{~min}$ com a mesma concentração de $\mathrm{NaOCl}$ (Tabela 1). Em todos os tratamentos a contaminação por bactérias foi maior em relação à contaminação fúngica. A condição fitossanitária da planta matriz é importante na medida em que irá determinar a facilidade de se descontaminar o explante durante $o$ isolamento $[1,16]$. A utilização de benomyl durante todo o período que antecedeu ao isolamento, certamente reduziu a contaminação fúngica, cuja redução, também foi obtida por Haldeman et al, 1987 [10]. Rey et al, 1991 [22] também salientam as dificuldades da implantação de cultivos de erva-mate devido à contaminação por fungos e bactérias.

TABELA 1 - Efeito da concentração de hipoclorito de sódio e período de exposição na desinfestação de explantes nodais de Ilex paraguariensis St. Hil, Curitiba, PR, 1991/92

\begin{tabular}{ccccccc}
\hline \multirow{2}{*}{ Tratamentos } & $\mathrm{NaOCl}$ & \multicolumn{2}{c}{ Período de } & \multicolumn{2}{c}{ Contaminação } & \multicolumn{2}{c}{ Oxidação } & Sobrevivência \\
\cline { 2 - 6 } & $(\%)$ & Exposição (min) & Bactéria (\%) & Fungo (\%) & $(\%)$ & $(\%)$ \\
\hline 1 & 0,50 & 5 & 40,0 & 11,4 & 1,4 & 47,2 \\
2 & 10 & 24,2 & 7,1 & 2,8 & 65,9 \\
3 & 0,50 & 15 & 17,1 & 7,1 & 7,1 & 68,7 \\
4 & 0,50 & 5 & 35,7 & 10,0 & 1,4 & 52,9 \\
5 & 0,75 & 10 & 15,7 & 5,7 & 5,7 & 72,9 \\
6 & 0,75 & 15 & 14,2 & 5,7 & 11,4 & 68,7 \\
\hline
\end{tabular}

\section{b) Oxidação}

A imersão dos explantes durante $15 \mathrm{~min}$ em solução de $\mathrm{NaOCl}$ a $0,75 \%$ promoveu a maior taxa de oxidação $(11,4 \%)$. As menores percentagens $(1,4 \%)$ foram obtidas com os tratamentos 1 e 4 onde o tempo de exposição ao agente desinfestante foi menor (Tabela 1). De acordo com George, 1993 [7], a concentração e o tempo de exposição aos desinfestantes dependem do material vegetal e diferentes partes da planta apresentam respostas variadas quanto à sensibilidade dos tecidos. Uma desinfestação eficiente elimina os microorganismos e não causa danos ou morte aos tecidos. Após a desinfestação os explantes foram imersos em água deionizada e esterilizada e, em seguida foram inoculados em tubo de ensaio após excisão, em ação rápida, reduzindo dessa forma o tempo de contato com 0 ar. Essas foram medidas que certamente reduziram os percentuais de oxidação nesse trabalho.

\section{c) Sobrevivência}

Os melhores resultados foram obtidos em 0,50 ou $0,75 \%$ de $\mathrm{NaOCl}$ durante os maiores períodos de exposição (10 e $15 \mathrm{~min}$ ) com valores muito próximos (72,9 e 68,7\%), conforme a Tabela 1. Os índices de sobrevivência estiveram diretamente relacionados aos de contaminação, visto que os explantes contaminados foram considerados inadequados para as demais etapas in vitro. Devido aos baixos índices de oxidação, esta não teve grande influência nas taxas de sobrevivência.

\section{Obtenção de brotações múltiplas}

O tratamento que propiciou o maior índice de brotações múltiplas de erva-mate foi $8,87 \mu \mathrm{M}$ de BAP no meio WPM após 3 subcultivos, com média de 3,75 brotações/explante (Tabela 2). Não houve diferença significativa para os meios de cultura MS e WPM (Teste KW, $\mathrm{H}=1.33$ ). Sansberro et al., 1999 [26] obtiveram a regeneração de brotações de erva-mate em meio MS/4 na ausência de reguladores de crescimento. Entretanto, o meio de cultura contendo BA produziu média de quatro brotações por explante. Tang et al., 1996 [27] verificaram para Alnus cremastogyne que o meio WPM foi eficiente para todas as etapas da micropropagação.

Os meios de cultura utilizados para a obtenção de brotações múltiplas podem conter baixas dosagens de auxina, a qual pode estimular o crescimento [2]. As concentrações de AIB adicionadas, mostraram efeitos diferentes para os meios MS e WPM para todos os subcultivos. O meio WPM acrescido de BAP e na ausência de auxina apresentou um número médio de brotações maior do que quando se adicionou $\operatorname{AIB}(F=9,16)$. Contrariamente, no meio MS se observou uma 
TABELA 2 - Número médio de brotações de llex paraguariensis St. Hil., cultivadas in vitro nos meios WPM e MS, acrescidos de $8,87 \mu \mathrm{M}$ de BAP e submetidos à s concentrações de AIB $(0 ; 0,24 ; 0,98$ e 1,48 $\mu \mathrm{M})$ em três subcultivos, Curitiba, PR, 1991/92 ${ }^{1}$

\begin{tabular}{|c|c|c|c|c|c|c|c|c|}
\hline \multirow[t]{2}{*}{ Subcultivo\AIB } & \multicolumn{3}{|c|}{ WPM } & & \multicolumn{3}{|c|}{ MS } & \\
\hline & 0,00 & 0,24 & 0,98 & 1,48 & 0,00 & 0,24 & 0,98 & 1,48 \\
\hline 1 & $\begin{array}{l}2,77 \\
(35)\end{array}$ & $\begin{array}{l}2,73 \\
(30)\end{array}$ & $\begin{array}{l}2,52 \\
(36)\end{array}$ & $\begin{array}{l}2,45 \\
(40)\end{array}$ & $\begin{array}{l}2,43 \\
(39)\end{array}$ & $\begin{array}{l}2,50 \\
(20)\end{array}$ & $\begin{array}{l}2,66 \\
(30)\end{array}$ & $\begin{array}{l}2,71 \\
(35)\end{array}$ \\
\hline 2 & $\begin{array}{l}3,21 \\
(32)\end{array}$ & $\begin{array}{l}3,20 \\
(29)\end{array}$ & $\begin{array}{l}2,93 \\
(32)\end{array}$ & $\begin{array}{l}2,89 \\
(38)\end{array}$ & $\begin{array}{l}2,85 \\
(34)\end{array}$ & $\begin{array}{l}2,75 \\
(16)\end{array}$ & $\begin{array}{l}3,20 \\
(24)\end{array}$ & $\begin{array}{l}3,25 \\
(31)\end{array}$ \\
\hline 3 & $\begin{array}{l}3,75 \\
(28)\end{array}$ & $\begin{array}{l}3,70 \\
(27)\end{array}$ & $\begin{array}{l}3,25 \\
(31)\end{array}$ & $\begin{array}{l}3,17 \\
(35)\end{array}$ & $\begin{array}{l}2,81 \\
(32)\end{array}$ & $\begin{array}{l}2,86 \\
(15)\end{array}$ & $\begin{array}{l}3,29 \\
(24)\end{array}$ & $\begin{array}{l}3,35 \\
(31)\end{array}$ \\
\hline $\begin{array}{c}\text { Média } \\
\text { Desvio Padrão }\end{array}$ & $\begin{array}{l}3,2105 \\
1,2956\end{array}$ & $\begin{array}{l}3,1977 \\
1,2539\end{array}$ & $\begin{array}{c}2,8889 \\
1,068\end{array}$ & $\begin{array}{l}2,823 \\
0,928\end{array}$ & $\begin{array}{c}2,6857 \\
0,964\end{array}$ & $\begin{array}{l}2,6863 \\
0,9485\end{array}$ & $\begin{array}{l}3,0256 \\
1,0565\end{array}$ & $\begin{array}{l}3,0928 \\
0,9138\end{array}$ \\
\hline $\mathrm{N}^{2}$ & 95 & 86 & 99 & 113 & 105 & 51 & 78 & 97 \\
\hline
\end{tabular}

Os valores entre parênteses correspondem ao número de explantes avaliados.

$\mathrm{N}=$ Tamanho da amostra. (Kruskal-Wallis e análise de regressão)

tendência de aumento no número de brotações com o aumento das concentrações de AIB ( $F=12,17)$. Esse resultado inverso entre os meios MS e WPM pode ser atribuído à composição diferente desses meios de cultura. Mc Cown e Sellmer, 1987 [18] afirmam que $\mathrm{o}$ efeito dos reguladores de crescimento pode ser modificado em função do meio de cultura utilizado. O meio WPM é uma formulação mais diluída de minerais quando comparada à do meio MS, sendo que uma das principais diferenças entre elas diz respeito aos teores de nitrogênio. A formulação salina WPM apresenta na sua composição menor concentração de nitrogênio e potássio e menor força iônica total [11]. O nitrogênio nas formas de amônio e nitrato e a razão entre eles pode interferir na diferenciação, na desdiferenciação, no crescimento e no desenvolvimento dos explantes ou na formação de órgãos [20]. A interação entre uma auxina e uma citocinina adicionada ao meio de cultura é complexa e fatores nutricionais podem interferir no resultado final [4]. Preece,1995 [20] comenta sobre a necessidade de estudos mais aprofundados nas interações entre os nutrientes do meio de cultura e os reguladores de crescimento.

O número de brotações tende a aumentar, em ambos os meios, em função do subcultivo. O efeito das citocininas não se restringiu a um subcultivo pois, diversas vezes, constatou-se um efeito residual de um subcultivo para outro, aumentando assim as taxas de multiplicação. Também Ribas, 1992 [23] obteve maiores taxas médias de regeneração de brotações em perobarosa no terceiro subcultivo, quando comparado ao primeiro e segundo subcultivos.

Ao se subcultivar brotações de erva-mate em meio de cultura acrescido de BAP, por longos períodos, observou-se que as brotações adquiriram coloração mais clara e tiveram seu crescimento interrompido. Huetteman e Preece, 1993 [13] sugeriram que deveria ser utilizado um meio de cultura primário para a indução de taxas elevadas de regeneração de brotações, as quais, posteriormente poderiam ser transferidas para meios de cultura secundários com outras combinações de reguladores de crescimento.

\section{Enraizamento}

Como se vê na Tabela 3 o melhor resultado para o enraizamento de brotações de erva-mate foi obtido em duas fases, indução e desenvolvimento das raízes. A concentração de $14,7 \mu \mathrm{M}$ de AIB induziu a formação de raízes no meio WPM/2 em $86,2 \%$ das brotações. Os resultados atribuídos às diferentes concentrações de AIB diferiram estatisticamente entre si. A adição de AIB no meio de cultura foi essencial ao enraizamento, porém, concentrações mais elevadas que $14,7 \mu \mathrm{M}$ reduziram-no. Para estacas de erva-mate uma concentração excessiva de AIB pode ser tóxica para a iniciação e desenvolvimento do sistema radical [8].

A permanência das brotações em meio de indução acrescido de AIB por 12 dias e posterior, transferência das brotações para o meio WPM/2 + $1 \mathrm{~g} \cdot \mathrm{L}^{-1}$ de carvão ativado, levou a aumento significativo na taxa de enraizamento quando comparadas com as brotações mantidas em meio com AIB por 30 dias (Teste de KW, $\mathrm{P}<0.01$ ). Isso pode ser explicado pelo fato da primeira fase ser dependente de auxina e o crescimento e alongamento das raízes ser inibido pela mesma [15]. Esses resultados confirmam os obtidos por [2, 9, 23] com maiores taxas de enraizamento quando o mesmo foi realizado em duas fases. Rey e Mroginski, 1988 [21] verificaram para erva-mate uma taxa de média de enraizamento de $50 \%$. Nesse caso a indução de iniciação radical ocorreu como resposta ao tratamento com $100 \mathrm{mg}^{-1} \mathrm{~L}^{-1}$ de AIB durante quatro horas com posterior transferência para meio MS/4. Também para essa espécie, Sansberro et al., 1999 [26] obtiveram 63\% de enraizamento em meio $\mathrm{MS} / 4+7.4 \mu \mathrm{M}$ de AIB posteriormente transferidas para meio $\mathrm{MS} / 4$ isento de reguladores de crescimento.

A concentração e o tempo de exposição ao tratamento com AIB são fatores críticos para a indução de raízes e para os clones de Quercus testados o carvão ativado beneficiou a qualidade das brotações, o desenvolvimento do sistema de raízes e a maior formação de raízes laterais [25]. 
TABELA 3 - Enraizamento in vitro de brotações de llex paraguariensis St. Hil. que permaneceram 30 dias em meio indutor e brotações que passaram por 12 dias em meio indutor e depois foram transferidas para meio de desenvolvimento das raízes, Curitiba, PR, 1991/92

\begin{tabular}{ccccc}
\hline \multirow{2}{*}{$\begin{array}{c}\text { AIB } \\
(\mu \mathrm{M})\end{array}$} & \multicolumn{4}{c}{ Período de exposição * } \\
\cline { 2 - 5 } & $\begin{array}{c}\text { Enraizamento } \\
(\%)\end{array}$ & $\mathrm{N}^{\circ}$ médio de raízes/explante & $\begin{array}{c}\text { Enraizamento } \\
(\%)\end{array}$ & $\mathrm{N}^{\circ}$ médio de raízes/explante \\
\hline 0 & 0 & 0 & 0 & 0 \\
14,7 & 20,00 & 1,66 & $86,20 *$ & 8,20 \\
19,6 & 15,38 & 2,00 & $66,66^{*}$ & 6,35 \\
24,6 & 11,53 & 2,00 & $63,33^{*}$ & 9,74 \\
\hline
\end{tabular}

diferenças significativas $[\mathrm{P}<0.01$ (Kruskal-Wallis)]

No presente trabalho, os melhores resultados, quanto ao número médio de raízes/explante, também foram obtidos em meio de duas fases acrescidos de 14,$7 ; 19,6$ e $24,6 \mu \mathrm{M}$ de AIB (Tabela 3). Brotações com maior número de raízes, certamente, terão melhor sobrevivência após o transplantio para terra quando comparadas às brotações com poucas raízes.

\section{CONCLUSÕES}

Os resultados obtidos no presente trabalho contribuíram para o avanço no conhecimento dos principais fatores que controlam a morfogênese in vitro da erva-mate para plantas de dois anos de idade e sugerem um protocolo de micropropagação:

a) o estabelecimento de culturas assépticas por meio da desinfestação com hipoclorito de sódio a $0,75 \%$ durante 10 minutos;

b) a obtenção de brotações múltiplas por cultura in vitro de segmentos nodais durante três subcultivos no mesmo meio de cultura (WPM + 8,87 $\mu$ M BAP); e

c) a indução de raízes pela permanência das brotações durante 12 dias num meio WPM/2 suplementado com $14,7 \mu \mathrm{M}$ de AIB seguida da transferência para outro meio WPM/2 isento de reguladores de crescimento e adicionado de $1 \mathrm{~g} . \mathrm{L}^{-1}$ de carvão ativado.

\section{REFERÊNCIAS}

[1] CHALUPA, V. In vitro propagation of birch (Betula verrucosa Ehrl.). Biologia Plantarum, Prague, v.23, p. 472-474, 1981.

[2] CHALUPA, V. European hardwoods. In: BONGA, J. M.; DURZAN, D. J. Cell and tissue culture in forestry. Dordrecht: Martinus Nijhoff Publishers, 1987. p. 224-246. (v.3)

[3] CUNHA, G. G. Cultura de embriões de erva-mate (Ilex paraguariensis St. Hil.) in vitro. Porto Alegre: 1990. 51 f. Dissertação (Mestrado em Fisiologia Vegetal) - Curso de Pós-Graduação em Fisiologia Vegetal, Universidade Federal do Rio Grande do Sul.

[4] DODDS, J. H.; ROBERTS, L. H. Experiments in plant tissue culture. New York: Cambridge University, 1982. $178 \mathrm{p}$

[5] EDWIN, G.; REITZ, P. R. Aquifoliáceas. Flora Ilustrada Catarinense. Itajaí: Herbário Barboza Rodrigues, 1967. $47 \mathrm{p}$.
[6] FERREIRA, A. G.; CUNHA, G. G.; SILVEIRA, T. S.; $\mathrm{HU}, \mathrm{C}$. Y. In vitro germination of immature embryos of Ilex paraguariensis St. Hil. Phyton, Vicente López, v.52, n.1, p. 27-32, 1991.

[7] GEORGE, E. F. Plant propagation by tissue culture: the technology. Edington: Exegetics Limited, 1993. 574 p. (v.1).

[8] GRAÇA, M. E. C.; COOPER, M. A.; TAVARES, F. R.; CARPANEZZI, A. A. Estaquia de erva-mate. Curitiba: EMBRAPA, 1988. 6 p. (Circular Técnica n.18).

[9] GUPTA, P. K.; TIMMIS, R.; CARLSON, W. C. Somatic embryogenesis: a possible tool for large scale propagation of forestry species. In: SOH, W. Y.; LIU, J. R.; KOMANINE, A. (Ed.) Advances in developmental biology and biotechnology of higher plants. Korean Society of Plant Tissue Culture, 1993. p. 18-37.

[10]HALDEMAN, J. H.; THOMAS, R. L.; McKAMY, D. L. Use of benomyl and rifampicin for in vitro shoot tip culture of Cammelia sinensis and C. japonica. HortScience, Alexandria, v.22, n.2, p. 306-307, 1987.

[11]HARRY, I. S.; THORPE, T. A. In vitro culture of forestry trees. In: VASIL, I. K.; THORPE, T. A. Plant cell and tissue culture. Dordrecht; Kluwer Academic, 1994. p. $539-560$.

[12] HU, C. Y. In vitro culture rudimentary embryos of eleven Ilex species. Journal of the American Society for Horticultural Sciences, New Jersey, v.100, n.3, p. 221-225, 1975.

[13] HUETTEMAN, C. A.; PREECE, J. E. Thiadiazuron: a potent cytokinin for wood plant tissue culture. Plant Cell Tissue and Organ Culture, Dordrecht, v.33, p. 105-109, 1993.

[14]INOUE, M. T.; RODERJAN, C. V.; KUNIYOSHI, Y. S. Projeto madeira do Paraná. Curitiba: Fundação de Pesquisas Florestais do Paraná, 1984. 260 p.

[15]JAMES, D. J.; THURBON, I. J. Rapid in vitro rooting of the apple rootstock M-9. Journal of Horticultural Science; Ashford, v.54, n.4, p. 309-311, 1979.

[16] JUNCKER, B.; FAVRE, J. M. Long-term effects of culture establishment from shoot-tip explants in micropropagation oak (Quercus robur. L.) Annales des Sciences Forestières, Paris, v.51, n.6, p. 581-588, 1994.

[17] LLOYD, G. H.; McCOWN, B. H. Commercially feasible micropropagation of mountain laurel (Kalmia latifolia) by use of shoot-tip culture. Proccedings of Annual Meetings - International Plant. Propagator's Society, Washington, v.30, p. 421-427, 1980.

[18] McCOWN, B. H.; SELLMER, J. C. General media and vessels suitable for wood plant culture. In: BONGA, J. M.; DURZAN, D. J. (Ed.) Cell and tissue culture in forestry. Dordrecht: Martinus Nijhoff Publishers, 1987, p. 4-13. (v.1).

[19]MURASHIGE, T.; SKOOG, F. A revised medium for rapid growth and bioassays with tobacco tissue culture. Physiologia Plantarum, Copenhagen, v.15, p. 473497, 1962. 
[20]PREECE, J. E. Can nutrient salts partially substitute for plant growth regulators? Plant Tissue Culture and Biotechnology, Israel, v.1, n.1, p. 26-37, 1995.

[21]REY, H. Y.; MROGINSKI, L. A. Regeneración de plantas de yerba mate (Ilex paraguariensis) por cultivo in vitro de ápices caulinares y segmentos nodales. Phyton, Vicente López, v.48, n.1-2, p. 139-145, 1988.

[22]REY, H. Y. ; BURTNIK, O. J.; SANSBERRO, P. A .; MROGINSKI, L. A. Medios de cultivos para el estabelecimento in vitro de explantos de la yerba mate (Ilex paraguariensis). Turrialba, San Jose, v.41, n.3, p. 306-310, 1991.

[23]RIBAS, L. L. F.; ZANETTE, F. Propagação da macieira cv. Gala através da cultura de meristemas. Revista Brasileira de Fisiologia Vegetal, Brasília, v.4, n.1, p. 39-43, 1992.

[24]RIBAS, L. L. F. Morfogênese in vitro e micropropagação de Aspidosperma polyneuron
Mull. Arg. (peroba-rosa). Curitiba: 1999. 175 f. Tese (Doutorado em Engenharia Florestal - Silvicultura) Setor de Ciências Agrárias, Universidade Federal do Paraná.

[25]SANCHEZ, M. C.; SAN-JOSÉ, M. C.; BALLESTER, A.; VIEITEZ, A. M. Requirements for in vitro rooting of Quercus robur and $Q$. rubra shoots derived from mature trees. Tree Physiology, Victoria, v.16, n.8, p. 673-680, 1996.

[26]SANSBERRO, P.; REY, L.; MROGINSKI, L.; COLLAVINO, M. In vitro plant regeneration of Ilex paraguariensis (Aquifoliaceae). In Vitro Cellular Developmental Biology Plant, Oxon, v.35,p. 401-402, 1999.

[27]TANG, D.; ISHII, K. In vitro regeneration of Alnus cremastogyne Burk from epicotyl explants. Plant Cell Reports, Heidelberg, v.15, p.658-661, 1996

Recebido para publicação em 06 NOV 1999 [SA 012/1999] Aceito para publicação em 03 JAN 2002 